\title{
PV sector in the European Union countries - Clusters and efficiency
}

\author{
Florinda Martins \\ REQUIMTE/ISEP, Rua Dr. António Bernardino de Almeida 431, Porto, Portugal
}

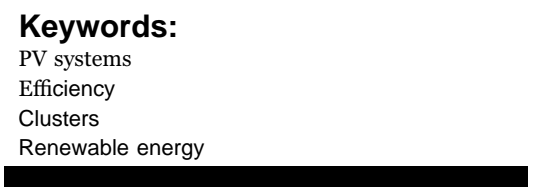

\begin{abstract}
A B S T R A C T
European Union (EU) due to several challenges that exist nowadays has changed its Energy Policy. In order to fulfill international commitments concerning greenhouse gas emission and to assure safety in supply and stable prices, EU has been a leader in renewable energy. In many EU countries solar energy is a possible and very viable option. Together with wind energy, photovoltaic energy is the new support core of a low carbon EU economy in what concerns electricity production. In this work clusters of countries were generated based on the energy produced by PV systems and the share of energy from PV systems in the total electricity produced by renewable sources. This work also analyzed the production of energy from the photovoltaic sector in EU and compared it with the existing potential for this type of energy. Roughly half of the EU countries are producing energy within the limits of what is expected, considering the irradiation on optimally inclined plane. However some of them could improve the ratio between energy production and installed power. Considering the leader countries in energy production from photovoltaic, Czech Republic and Spain are the countries that exceed what it is expected.
\end{abstract}

\section{Introduction}

Energy is very important to all human activities and for that reason it is a major concern for countries worldwide. In addition, energy demand is foreseen to increase [1] and conventional sources are unevenly distributed [2] and are fast depleting. Coal although more widely distributed and more abundant has many environmental problems when used in energy production. In recent years renewable energy has becoming increasingly a key factor to access clean, secure and affordable energy in the future [3]. EU has a high external energy dependency [4] what increases its vulnerability to instable markets and prices. Furthermore climate change and other environmental problems related to the use of fossil fuels led to a shift in EU Energy Police. The Energy/Climate package is a signal that EU intends to promote more sustainable ways for producing energy taking advantage of the potential of local/country characteristics. Fukushima accident made nuclear energy not so attractive [5] which in turn may favor renewable energy. Hydropower has already a consolidated position [6] but in electricity production wind and photovoltaic energy have been the major emerging technologies. The energy policies and the support mechanisms have contributed to its implementation [7] and research has reduced its costs and accelerated deployment. Renewable energy policy instruments play a very important role in the development and implementation of renewable energy sources not only in EU but also in countries located in other regions [8-10]. According to the results of studies, feed-in tariffs are one the most effective instruments [11,12]. However the decreasing prices of the photovoltaic cells induced large changes in many countries which showed that those instruments should be carefully thought, taking in consideration several factors. Moreover new methodologies to assess sustainability of energy systems are being developed which provide a better understanding of different aspects involved in energy sustainability [13,14].

PV systems are usually classified in first, second and third generation depending on the basic material use and the level of commercial maturity [15]. The first generation systems are the wafer-based crystalline silicon (mono and multi), second generation uses the thin film technology (e.g. cadmium-telluride, copper-indium-selenide, etc,) and the third generation uses other technologies (e.g. dye-sensitized, organic/polymer, etc.). The advantages of thin film technology include the reduction of materials and the fact that can be easily used in building components (Building integrated PV, BIPV) [15]. Crystalline silicon is the most used material in PV industry and crystalline silicon wafers presents the highest share of market in 2013 with 91\% [16]. In EU around $85 \%$ of all new PV systems are still based on crystalline silicon technology, which is a mature technology [17]. Photovoltaic is a sector in expansion and in 2014 was another year of strong growth, despite the reduction in new installations in the European Union because national targets are in the way of being reached [18]. In order to continue this growth it is important to have qualified technicians with skills related to installation and maintenance of PV systems, what will support and strength this sector. Europe has already projects on this matter [19]. From an economic perspective the locations where the 
LCOE (Levelized Cost of Energy) is lower than the retail price of electricity unsubsidized PV can be a complementary source of electricity. In EU LCOE values range from 9 EURcts/kWh in the southern Mediterranean to 22-23EURcts/kWh in the most northern regions. This variation is due to geographical differences in annual insolation and also to national sales tax rates [20]. In addition some authors create other frameworks that consider the full cost of electricity, by incorporating economic and environmental externalities, what can increase the information provided for the decision-makers [21]. To be able to predict the future cost of PV technology is very important for energy policies design, however the several existing studies [22-24] raise issues about the comparability of the results [25]. Although being considered a mature technology, different aspects of photovoltaic techniques and technologies are still being explored (e.g. Maximum power Point tracking (MPPT) algorithms and bifacial solar photovoltaic) $[26,27]$ and different uses are being tough and implement, such as their use in buildings [28-32]. In fact PV technology can contribute to a low carbon energy system. Considering the two scenarios from IEA (International Energy Agency) for the period 2013-2050, namely 2DS and Roadmap, $15.4 \mathrm{Gt} \mathrm{CO}_{2}$ and $22.5 \mathrm{Gt} \mathrm{CO}_{2}$ respectively can be saved for European Union-27 [33].

At this point it is important to analyze the similarities of countries, concerning energy production from PV systems. Moreover it is a key aspect to analyze the efficiency of the photovoltaic existing systems in a macro perspective, taking in consideration the energy produced, the installed capacity and the potential for producing energy. The aim of this work was to analyze the similarities by applying k-means clustering, to identify the main groups of EU countries according to their energy production from PV systems and the contribution of that energy to the total renewable energy produced. Another goal was to compare the energy produced from PV systems in each country with what would be expected taking in consideration the average irradiation and the existing technology.

\section{Energy production from photovoltaic systems and installed capacity}

In 2014 the EU - 28 countries produced 91 TWh of energy from photovoltaic systems [34]. Table 1 presents the contribution of each country. It is possible to conclude that the 10 top countries are Germany, Italy, Spain, France, United Kingdom, Greece, Belgium, Czech Republic, Romania and Bulgaria, all of them with an energy production above $1 \mathrm{TWh}$. Although the production in two countries alone, namely Germany and Italy amount for more than $50 \%$ of the energy produced. The potential for energy production varies with the location of the countries, namely with latitude and longitude since the irradiation is different. Fig. 1 presents the average irradiation on optimally inclined plane (Wh/ $\mathrm{m}^{2} /$ day) for the different countries of the EU. Several locations in each country were selected covering all

Table 1

Energy production and installed power in the top ten PV countries.

\begin{tabular}{llll}
\hline & $\begin{array}{l}\text { Energy } \\
\text { TWh [10] }\end{array}$ & $\begin{array}{l}\text { Energy production } \\
(\%)\end{array}$ & $\begin{array}{l}\text { Installed power } \\
\text { MW [10] }\end{array}$ \\
\hline Germany & 34.930 & 38.25 & $38,301.0$ \\
Italy & 23.299 & 25.51 & $18,450.0$ \\
Spain & 8.211 & 8.99 & 4787.3 \\
France & 5.500 & 6.02 & 5600.0 \\
United Kingdom & 3.931 & 4.30 & 5230.3 \\
Greece & 3.856 & 4.22 & 2602.8 \\
Belgium & 2.768 & 3.03 & 3105.3 \\
Czeh Republic & 2.122 & 2.32 & 2061.0 \\
Romania & 1.355 & 1.48 & 1292.6 \\
Bulgaria & 1.245 & 1.36 & 1020.4 \\
All other countries & 4.102 & 4.49 & 4223.40 \\
Total & 91.32 & 100.0 & $86,674.10$ \\
\hline
\end{tabular}

territory and the irradiation for each location gathered from [35]. Then was calculated the average value for each country and the standard deviation. The countries located in the south, near the Mediterranean present the highest values, namely Cyprus, France, Greece, Italy, Portugal, Spain and Malta as expected and mentioned by Hadjipanayi et al., 2016 [36]. There are countries with potential for producing energy from photovoltaic systems that are not taking advantage of their potential for this kind of renewable energy. Cyprus, Malta, Portugal are examples of this situation. Most countries present a standard deviation very small with the exception of the Mediterranean countries that present higher irradiation in the areas closed to the Mediterranean. Austria, Croatia and Romania are also countries that present high standard deviation.

For these countries that present high standard deviation the energy produced from power PV systems will be greatly affected by the location. Support mechanisms such as feed-in tariff (FIT) schemes have been used in many EU countries to promote renewable energy, such as solar based electricity generation. However they are being reduced and new regulations are being launch to continue to promote the development of renewable energy and support self-consumption. Measures such as net-metering and self-consumption are becoming increasingly popular [8,37]. In addition geographical parameters are rarely introduced in PV FIT value to account for the different solar radiation in the several regions [8].

\section{Methodology}

\subsection{Clusters $P V$ energy}

One of the goals of this work was to generate clusters of countries based on the energy produced by PV systems and the share of energy from PV systems in the total electricity produced by renewable sources (data from [38]). It was used the k-means clustering method which has already been used in the domain of renewable energy and other domains $[39,40]$. The k-means clustering divides the data space into a number of clusters, each one defined by a centroid and formed by the data for which the centroid is the nearest [41]. It is a classical widely used clustering analysis method because of its high efficiency and concise algorithm and can accommodate a large sample size. [40,42]. The application of this method had as purpose to identify the main groups of EU countries taking in consideration their energy production from PV systems and the contribution of that energy to the total renewable energy produced in each country.

\subsection{Expected energy production and efficiency indicator}

Another goal of this work was to compare the energy produced from PV systems in each country with what would be expected taking in consideration the average irradiation and the existing technology. The expected energy production can be estimated considering the irradiation on optimally inclined plane according to Eq. (1).

$E=A r H P R$

Where E is energy $(\mathrm{kWh}), \mathrm{A}$ is total solar panel area $\left(\mathrm{m}^{2}\right), \mathrm{r}$ is solar panel yield (\%), $\mathrm{H}$ is annual average solar radiation on panels (kWh/ $\mathrm{m}^{2} /$ day) and $\mathrm{PR}$ is the performance ratio, coefficient for losses (range between 0.5 and 0.9 , default value=0.75). In 2013 Mono-Crystalline Silicon (c-Si) and Multi-Crystalline Silicon (mc-Si) still dominated the market with 91\% [16]. Production of crystalline silicon cells and modules rose in 2014. Thin film production also increased around $25 \%$, with its share of total global PV production remaining at about $10 \%$ [18]. The confirmed solar cell efficiency is $20-24 \%$ for c-Si and $14-18 \%$ for the mc-Si [15]. In this work a value of $15 \%$ was considered to solar panel yield to be conservative and the default value for the coefficient for losses was used.

In addition it is also important to calculate an efficiency indicator 


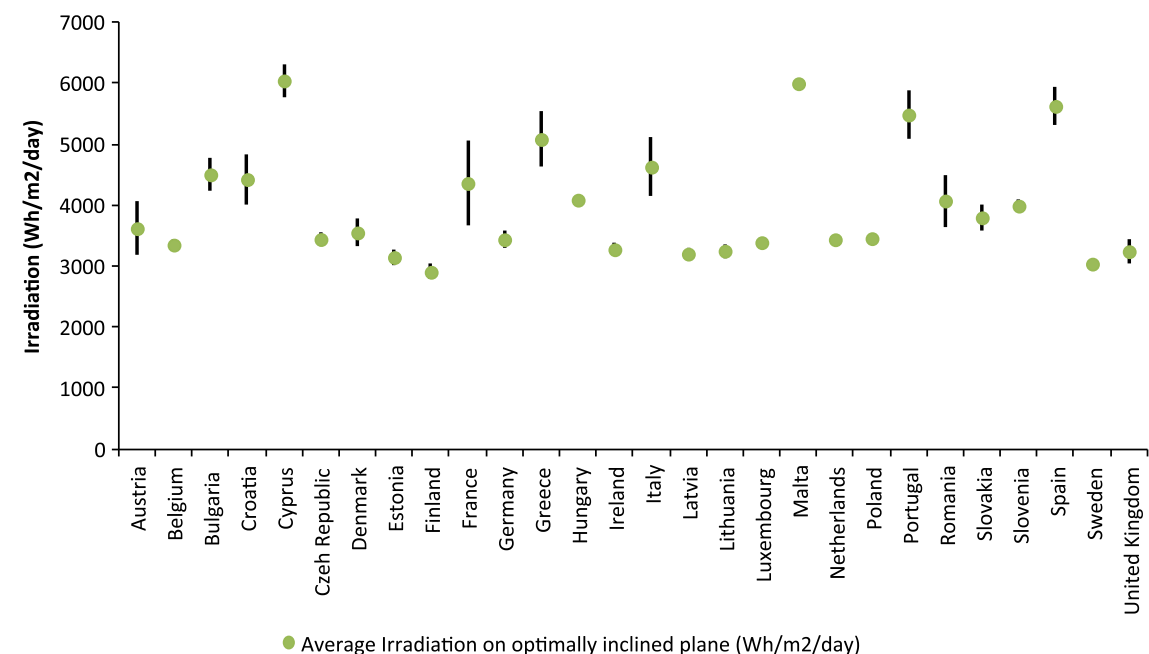

Fig. 1. Average and standard deviation of irradiation on optimally inclined plane for each country.

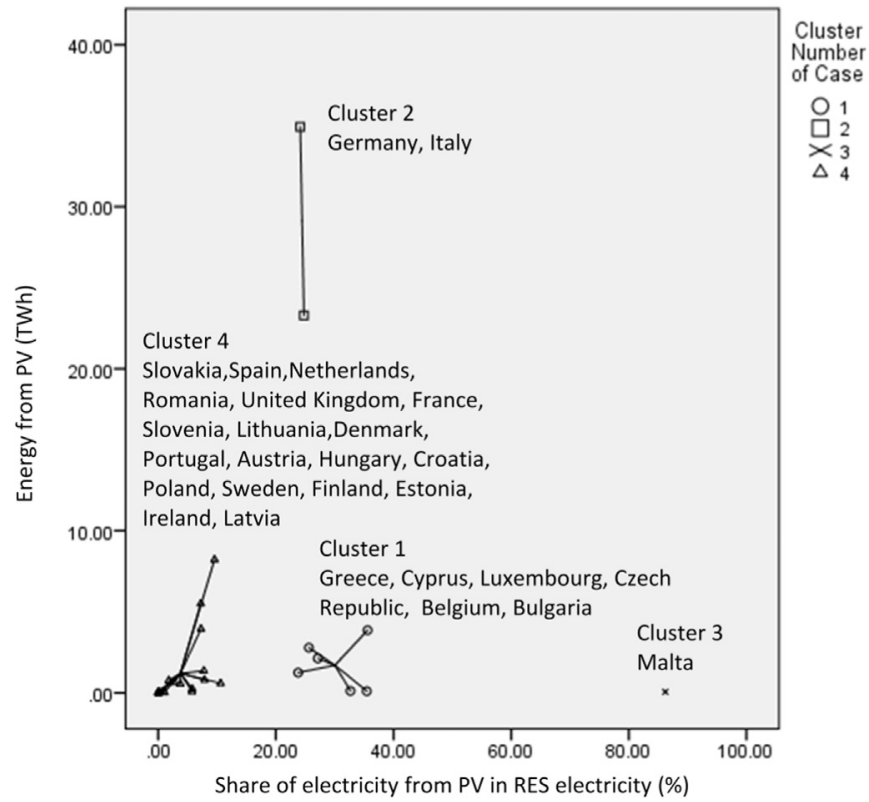

Fig. 2. PV Clusters 2014.

relating the energy output with the installed capacity for each country, comparing the real value of the indicator with the theoretical where the energy is calculated by Eq. (1).

The efficiency indicator can be calculated according to Eq. (2) [43]:

$I_{\text {Efficiency }}=\frac{\text { Energyproduced }}{\text { Installedcapacity }} T W h / G W$

\section{Results}

The application of k-means clustering algorithm using SPSS package generated four groups of countries presented in Fig. 2. The first group (cluster4) is formed by: Slovakia, Spain, Netherlands, Romania, United Kingdom, France, Slovenia, Lithuania, Denmark, Portugal, Austria, Hungary, Croatia, Poland, Sweden, Finland, Estonia, Ireland and Latvia. In these countries share of electricity from PV systems is less $10 \%$.

The second group (cluster 1) consists of: Greece, Cyprus, Luxembourg, Czech Republic, Belgium and Bulgaria. In this group share of electricity from PV systems is higher than $20 \%$ and less than $40 \%$. In the third group (cluster 2) is formed by Germany and Italy, the main producers of photovoltaic energy. In this group share of electricity from PV systems is higher than 20\% and less than 30\% but energy production from PV systems is higher than $20 \mathrm{TWh}$. The fourth group (cluster 3) has only one country: Malta. Malta has a share of electricity from PV systems that is higher than $80 \%$, however it presents a small energy production from PV. In the first group there are some countries that have higher energy production from PV systems than the rest of countries belonging to this group, namely Spain, France and the United Kingdom. In the second group there are two countries that can be distinguished by their extremely low production, Cyprus and Luxembourg. Germany and Italy are the leader countries in energy production from PV systems by far.

After defining the clusters the theoretical energy production for each country was calculated using Eq. (1) and the deviation calculated. Only 8 countries produced more than the theoretical amount namely Austria, Czech Republic, Greece, Lithuania, Luxembourg, Portugal, Spain and Sweden. Austria and Portugal however present a residual positive difference and Lithuania, Luxembourg and Sweden present a very low energy production, less than $0.15 \mathrm{TWh}$. Following this

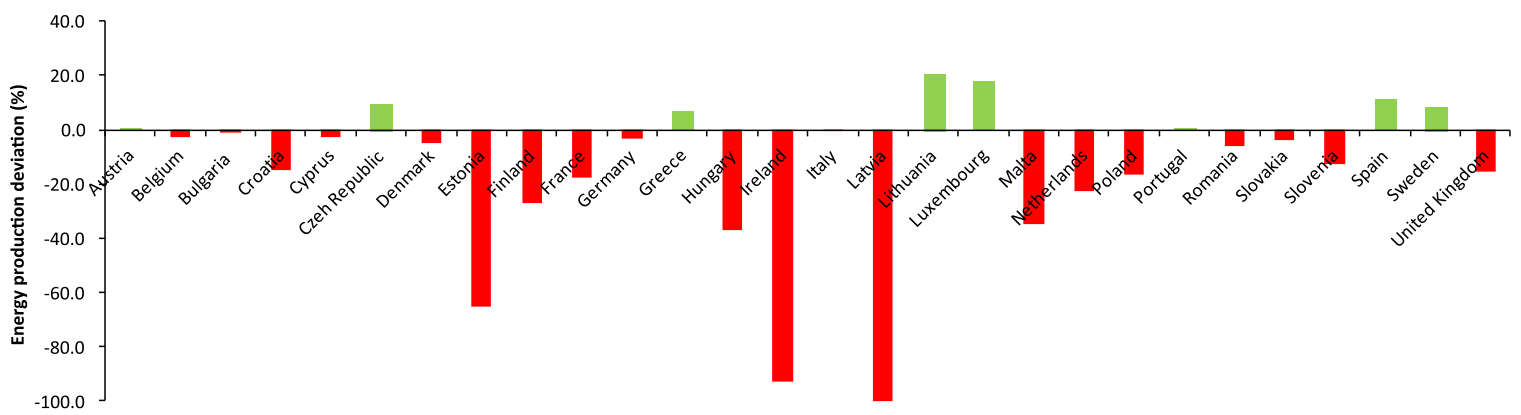

Fig. 3. Energy production deviation. 
Table 2

Maximum and minimum theoretical energy production and classification.

\begin{tabular}{|c|c|c|c|}
\hline & $\begin{array}{l}\text { Maximum theoretical } \\
\text { production (TWh) }\end{array}$ & $\begin{array}{l}\text { Minimum theoretical } \\
\text { production (TWh) }\end{array}$ & Classification \\
\hline Austria & 0.8560 & 0.6711 & Inside \\
\hline Belgium & 2.9228 & 2.7727 & Outside - Inferior \\
\hline Bulgaria & 1.3311 & 1.1852 & Inside \\
\hline Croatia & 0.0453 & 0.0376 & Outside - Inferior \\
\hline Cyprus & 0.1122 & 0.1023 & Inside \\
\hline Czeh Republic & 1.9998 & 1.8841 & Outside - Superior \\
\hline Denmark & 0.6217 & 0.5474 & Inside \\
\hline Estonia & 0.0002 & 0.0002 & Outside - Inferior \\
\hline Finland & 0.0085 & 0.0077 & Outside - Inferior \\
\hline France & 7.7569 & 5.6170 & Outside - Inferior \\
\hline Germany & 37.4893 & 34.6049 & Inside \\
\hline Greece & 3.9425 & 3.3024 & Inside \\
\hline Hungary & 0.0433 & 0.0422 & Outside - Inferior \\
\hline Ireland & 0.0010 & 0.0010 & Outside - Inferior \\
\hline Italy & 25.7935 & 20.9759 & Inside \\
\hline Latvia & 0.0014 & 0.0013 & Outside - Inferior \\
\hline Lithuania & 0.0627 & 0.0585 & Outside - Superior \\
\hline Luxembourg & 0.1047 & 0.0994 & Outside - Superior \\
\hline Malta & 0.0892 & 0.0888 & Outside - Inferior \\
\hline Netherlands & 1.0571 & 1.0134 & Outside - Inferior \\
\hline Poland & 0.0235 & 0.0226 & Outside - Inferior \\
\hline Portugal & 0.6756 & 0.5829 & Inside \\
\hline Romania & 1.5910 & 1.2922 & Inside \\
\hline Slovakia & 0.6462 & 0.5808 & Inside \\
\hline Slovenia & 0.2872 & 0.2721 & Outside - Inferior \\
\hline Spain & 7.7928 & 6.9585 & Outside - Superior \\
\hline Sweden & 0.0682 & 0.0639 & Outside - Superior \\
\hline United Kingdom & 4.9209 & 4.3629 & Outside - Inferior \\
\hline
\end{tabular}

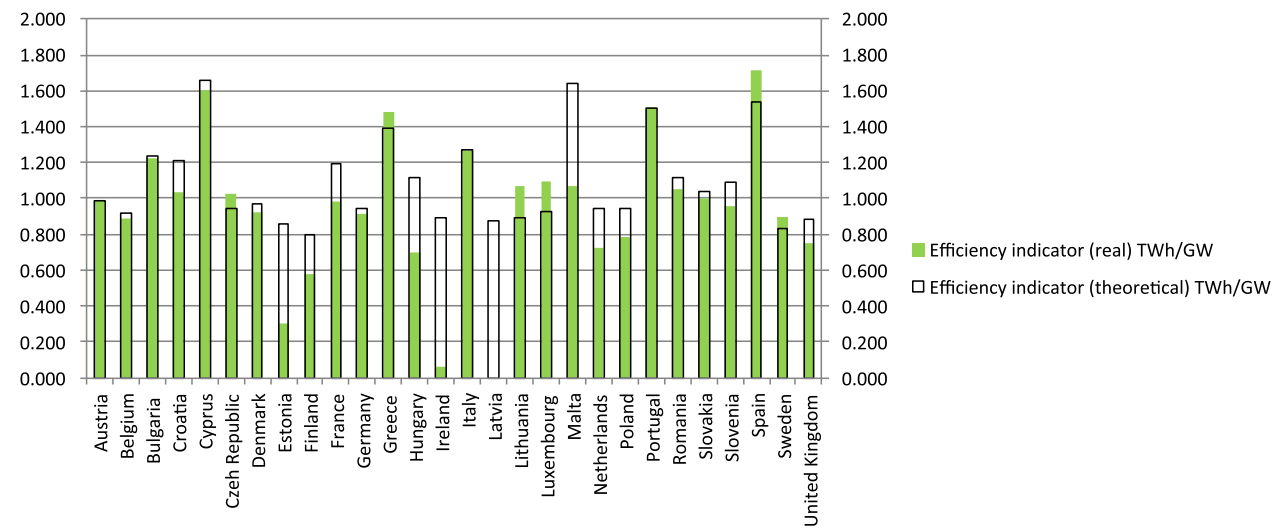

Fig. 4. Theoretical and real efficiency indicator.

analysis only three countries present a clear positive trend, namely Czech Republic, Greece and Spain. The three larger negative deviations are from countries where PV implementation is residual (installed power $<1.5 \mathrm{MW}$ ). Germany and Italy present small negative deviations (Fig. 3).

In the next step it was verified if the real energy production was within the limits defined by the standard deviation of the average irradiation on optimally inclined plane. Table 2 presents the results obtained. Analyzing the top ten countries it is possible to conclude that France, United Kingdom and Belgium are producing below the minimum theoretical production and that Czech Republic and Spain are producing above the maximum theoretical production. Germany is an important investor in solar energy technology with more than $60 \%$ of the total European Research expenditure [44], however it revealed a performance within the limits of what was expected.

In the next step the efficiency indicator was calculated and it was possible to conclude as expected that the countries have different values for this indicator. The theoretical range for the indicator is $0.79 \mathrm{TWh} / \mathrm{GW}$ for Finland and $1.66 \mathrm{TWh} / \mathrm{GW}$ for Cyprus (Fig. 4). The
Mediterranean countries present higher values for this indicator due the higher solar radiation. The highest values are for Cyprus, Greece, Italy, Malta, Portugal and Spain. Fig. 4 also presents the comparison between the theoretical and real efficiency indicator for each country. Czech Republic, Greece and Spain present a good performance and they are major contributors to energy production from PV systems. However energy produced in Greece is within the range expected as shown in Table 2.

The Spanish boom of PV installation happened in 2008 and for Czech Republic it was in 2010 [45]. Czech solar market owned its position due to favorable FIT (Feed-in-Tariff) with small yearly digression and the fall of modules prices [46]. Industrial groundmounted systems are by far the most common and the major contributors to total installed capacity in Czech Republic. The positive results obtained for Greece and Spain can be explained by the good characteristics of some locations of these countries concerning solar energy $[47,48]$. In Spain PV industry is characterized by medium to big ground-mounted installations. In the residential and commercial sectors there was not much activity because regulatory support has 
been insufficient [49]. However in Spain, BAPV (Building Applied Photovoltaic) and BIPV (Building-integrated photovoltaics) were about $34 \%$ of installed power in 2013 [50].

\section{Conclusions}

The analysis showed that the EU countries can be grouped in four clusters being the most important one constituted by Germany and Italy. These countries are the main producers of photovoltaic energy, being energy production from PV systems higher than 20 TWh and share of electricity from PV systems in the range 20-30\%. Considering the top ten EU countries it is possible to conclude that France, United Kingdom and Belgium are producing below the minimum theoretical production and that Czech Republic and Spain are producing above the maximum theoretical production. The performance of PV systems in Czech Republic and Spain outstand what was expected by theoretical calculations and their efficiency indicator is higher than the theoretical. The EU countries due to their specific characteristics present different indicator efficiencies for PV systems and there are some countries with high indicators that could increase the implementation of PV systems in order to profit from their natural resources and decrease their energy dependency. However the promotion of PV technology is not solely determined by technical parameters, it also depends of strategic, politic, economic and social factors.

\section{References}

[1] IEA (2014), World Energy Outlook. - Executive Summary; 2014

[2] Shafiee S, Topal E. When will fossil fuel reserves be diminished?. Energy Policy 2009;37:181-9.

[3] Giacomarra M, Bono F. EuropeanUnion commitmen towards res market penetration: from the first legislative acts to the publication of the recent guidelines on state aid 2014/2020. Renew Sustain Energy Rev 2015;47:218-32.

[4] European Commission, Imports and secure supplies, 2016, 〈http://ec.europa.eu/ energy/en/topics/imports-and-secure-supplies $\rangle$, accessed 24.03.201.

[5] Welsch H, Biermann P. Fukushima and the preference for nuclear power in Europe: evidence from subjective well-being data. Ecol Econ 2014;108(2014):171-9.

[6] Zimny J, Michalak P, Bielik S, Szczotka K. Directions in development of hydropower in the world, in Europea nd Poland in the period 1995-2011. Renew Sustain Energy Rev 2013;21:117-30.

[7] Abolhosseini S, Heshmati A. The main support mechanisms to finance renewable energy development\$. Renew Sustain Energy Rev 2014;40:876-85.

[8] Dusonchet L, Telaretti E. Comparative economic analysis of support policies for solar PV in the most representative EU countries. Renew Sustain Enetgy Rev 2015;42:986-98.

[9] Zou H, Du H, Ren J, Sovacool BK, Zhang Y, Mao G. Market dynamics, innovation, and transition in China's solar photovoltaic (PV) industry: a critical review. Renew Sustain Energy Rev 2017;69:197-206.

[10] Edalati S, Ameri M, Iranmanesh M, Tarmahi H, Gholampour M. Technical and economic assessments of grid-connected photovoltaic power plants: Iran case study. Energy 2016;114:923-34.

[11] Kilinc-Ata N. The evaluation of renewable energy policies across EU countries and US states: an econometric approach. Energy Sustain Dev 2016;31:83-90.

[12] Fouquet D, Johansson TB. European renewable energy policy at crossroads-Focus on electricity support mechanisms. Energy Policy 2008;36:4079-92.

[13] Iddrisu I, Bhattacharyya SC. Sustainable energy development index: a multidimensional indicator for measuring sustainable energy development. Renew Sustain Energy Rev 2015;50:513-30.

[14] Cosmi C, Dvarionienė J, Marques I, Di Leo S, Gecevičius G, Gurauskienė I, Mendes G, Selada C. A holistic approach to sustainable energy development at regional level: the renergy self-assessment methodology. Renew Sustain Energy Rev 2015;49:693-707.

[15] IRENA. Renewable energy technologies: cost analysis series, Vol. 1: Power Sector, Issue $4 / 5 ; 2012$

[16] Bhandari KP, Collier JM, Ellingson RJ, Apul DS. Energy payback time (EPBT) and energy return on enrgy invested (EROI) of solar photovoltaic systems: a systematic review and meta-analysis. Renew Sustain Energy Rev 2015;47:133-41.

[17] 〈https://setis.ec.europa.eu/technologies/solar-photovoltaic〉, (Accessed 25 may 2016)

[18] REN21. Renewables 2015 Global Status Report; 2015
[19] Tsoutsos TD, Tournaki SK, Gkouskos ZK, Despotou E, Masson G. Training and certification of PV installers in Europe. Renew Energy 2013;49:222-6.

[20] Huld T, Waldau AJ, Ossenbrink H, Szabo S, Dunlop E, Taylor N. Cost maps for unsubsidised photovoltaic electricity. European Commission; 2014.

[21] Benes KJ, Augustin C. Beyond LCOE: a simplified framework for assessing the full cost of electricity. Electr J 2016;29:48-54.

[22] Baker E, Chon H, Keisler J. Advanced solar R \& D: Combining economic analysis with expert elicitations to inform climate policy. Energy Econ 2009;31:537-49.

[23] Boseti V, Catenacci M, Fiorese G, Verdolini E. The future prospect of PV and CSP solar technologies: an expert elicitation survey. Energy Policy 2012;49:308-17.

[24] Curtright AE, Morgan MG, Keith DW. Expert assessments of future photovoltaic technologies. Environ Sci Technol 2008;42(24):9031-8.

[25] Verdolini E, Anadon LD, Lu J, Nemet GF. The effects of expert selection, elicitation design, and R \& D assumptions on experts'estimates of the future costs of photovoltaics. Energy Policy 2015;80:233-43.

[26] Enany M, Farahat MA, Nasr A. Modeling and evaluation of main maximum power point tracking algorithms for photovoltaics systems. Renew Sustain Energy Rev 2016;58:1578-86.

[27] Guerreo-Lemus R, Veja R, Kim T, Kimm A, Shepard LE. Bifacial solar photovoltaics - A technology review. Renew Sustain Energy Rev 2016;60:1533-49.

[28] Mohammadi K, Khorasanizadeh $\mathrm{H}$. A review of solar radiation on vertically mounted solar surfaces and proper azimuth angles in six Iranian major cities. Renew Sustain Energy Rev 2015;47:504-18.

[29] Ikkurti HP, Saha S. A comprehensive techno-economic review of microinverters for building integrated photovoltaics (BIPV). Renew Sustain Energy Rev 2015;47:997-1006.

[30] Wang C, Gong G, Su H, Yu CW. Efficacy of integrated photovoltaics-air source heat pump systems for application in Central-south China. Renew Sustain Energy Rev 2015;49:1190-7.

[31] Lang T, Gloerfeld E, Girod B. Don't just follow the sun - A global assessment of economic performance for residential building photovoltaics. Renew Sustain Energy Rev 2015;42:932-51.

[32] Loulas NM, Karteris MM, Pilavachi PA, Papadopoulos AM. Photovoltaics in urban environment: a case study for typical apartment buildings in Greece. Renew Energy 2012;48:453-63.

[33] Hernández-Moro J, Martínez-Duart JM. Economic analysis of the contribution of photovoltaics to the decarbonization of the power sector. Renew Sustain Energy Rev 2015;41:1288-97.

[34] EurObserver. Photovolatic barometer; 2015.

[35] European Commission, Photovoltaic Geographical Information System - Interactive Maps, 〈http://re.jrc.ec.europa.eu/pvgis/apps4/pvest.php?Lang=en \& map=europe $\rangle$, (Accessed in 21 march 2016.

[36] Hadjipanayi M, Koumparou I, Philippou N, Paraskeva V, Phinikarides A, Makrides G, Efthymiou V, Georghiou GE. Prospects of photovoltaics in southern European, Mediterranean and Middle East regions. Renew Energy 2016;92:58-74.

[37] Rodrigues S, Torabikalaki R, Faria F, Cafôfo N, Chen X, Ivaki AR, Mata-Lima E, Morgado-Dias F. Economic feasibility analysis of small scale PV systems in different countries. Sol Energy 2016;131:81-95.

[38] European Comission, Eurostat, $\langle\mathrm{http}$ //ec.europa.eu/eurostat/help/new-eurostatwebsite). (Accessed in 19 march 2016).

[39] Pacesila M, Burcea SG, Colesca SE. Analysis of renewable energies in European Union. Renew Sustain Energy Rev 2016;56:156-70.

[40] Li C, Sun L, Jia J, Cai Y, Wang X. Risk assessment of water pollution sources based on an integrated k-means clustering and set pair analysis method in the region of Shiyan, China. Sci Total Environ 2016;557-558:307-16.

[41] Barcena JF, Camus P, García A, Alvarez C. Selecting model scenarios of real hydrodynamic forcing on mesotidal and macrotidal estuaries influenced by river discharges using K-means clustering. Environ Model Softw 2015;68:70-82.

[42] Pandit YP, Badhe YP, Sharma BK, Tambe SS, Kulkarni BD. Classification of Indian power coals using K-means clustering and Self Organizing Map neural network. Fuel 2011;90:339-47.

[43] Martins F, Felgueiras C. RES efficiency indicators for Portugal, Spain and Germany. J Clean Energy Technol 2015;3(4):261-4.

[44] Corsatea TD. Technological capabilities for innovation activitiesacross Europe: Evidence from wind, solar and bioenergy technologies. Renew Sustain Energy Rev 2014;37:469-79.

[45] Pyrgou A, Kylili A, Fokaides PA. The future of the feed-in Tariff (fit) scheme in Europe: the case of photovoltaics. Energy Policy 2016;95:94-102.

[46] PV-NMS-NET. Status of Phtovoltaics New Member States 2010; 2011.

[47] Girard A, Gago EJ, Ordonez J, Muneer T. Spain's energy outlook: a review of PV potential and energy export. Renew Energy 2016;86:703-15.

[48] Patlitzianas KD, Skylogiannis GK, Konstantinos D. Assessing the PV business opportunities in Greece. Energy Convers Manag 2013;75:651-7.

[49] J. Danoso, P. Palencia, National Survey Report of PV Power Applications in Spain $2014 ; 2015$.

[50] UNEF, V. Salas, National Survey Report of PV Power Applications in Spain 2013; 2014. 